\title{
WOMEN TRAILBLAZERS IN THE LAW: THE NEW ZEALAND WOMEN JUDGES ORAL HISTORIES PROJECT
}

\author{
Elizabeth Chan*
}

The New Zealand Women Judges Oral Histories Project aims to provide the first national, publicly accessible records of the lives and careers of trailblazing women judges. As part of this project, this article shares the stories of nine women judges who have broken gender barriers at every stage of their legal studies and careers, including as the first women law graduates, partners of law firms, Queen's Counsel and judges. In sharing the challenges faced by, and celebrating the successes of, these women judges, their individual stories give context to the statistics showing that women's participation at the highest levels of the legal profession remains the exception rather than the norm. It is hoped that the achievements of the women who have gone before will inspire today's young women to reach positions of leadership in the profession, and, more broadly, to strive for equality in both their personal and professional lives.

\section{INTRODUCTION}

In 2003, Philip Girard wrote that in "Australia, New Zealand and Canada, the writing of judicial biography has been a somewhat halting and sporadic enterprise". ${ }^{1}$ In the past four years, the New Zealand Women Judges Oral Histories Project (Oral Histories Project) has made a systematic effort to record the life histories of 18 of New Zealand's women trailblazers in the judiciary. Drawing on the oral history interviews completed to date, this article shares the stories of nine women judges

* Elizabeth Chan, LLM candidate (Yale Law School), LLB (Hons), BA (University of Auckland). Elizabeth is a former clerk at the Supreme Court of New Zealand (2012-2014). The author is grateful to Dame Susan Glazebrook for the opportunity to work on the New Zealand Women Judges Oral Histories Project and for her invaluable support in the writing of this article. The author is also grateful to Dame Judith Potter, Dame Lowell Goddard, Judge Carolyn Henwood, Judge Shonagh Kenderdine, Judge Annis Somerville, Judge Stephanie Milroy, Judge Carrie Wainwright and Judge Caren Fox both for their permission to share their stories and for their feedback on this article.

1 Philip Girard "Judging Lives: Judicial Biography from Hale to Holmes" (2003) 7 AJLH 87 at 87. 
who have broken barriers at every stage of their legal studies and careers in becoming the first women law graduates, partners of law firms, Queen's Counsel (QC) and judges.

The purpose of publishing these stories is to share the perspectives of nine women judges on the way they perceived their gender to have affected the challenges they faced as pioneers in the law. By reading their life histories, we gain a more nuanced understanding, not only about how the women made sense of their own experiences through a gendered lens, but also how others (both men and women) reacted to their successes because they were women. It is hoped that this article will have particular relevance to young women in the law, as both a source of wisdom in understanding how women have succeeded in a male-dominated profession, as well as a source of inspiration as they, too, strive towards becoming leaders in the legal world. This article therefore makes a fitting contribution to the special edition of the Victoria University of Wellington Law Review as a tribute to one of New Zealand's first trailblazing women lawyers: Harriette Vine, the first woman law graduate of Victoria University of Wellington.

This article will discuss the Oral Histories Project in three parts. Part II provides an overview of this project, explaining its objectives and methodology. Part III discusses oral history as a methodology and its importance in recording the unheard stories of women. It also discusses the limitations of using oral history as a source of historical evidence. Part IV explores two major themes emerging from the first nine interviews conducted with current and retired women judges. The first theme identifies the challenges the women judges faced because of their gender and their attempts to break gender barriers during both their legal education and careers. The second theme introduces Māori perspectives by drawing on the experiences of two Māori women judges and a Pakeha woman judge with extensive experience in te ao Māori.

\section{THE ORAL HISTORIES PROJECT \\ A Overview of the Oral Histories Project}

The New Zealand Association of Women Judges is in the final stages of a three-year project interviewing women judges. ${ }^{2}$ The Oral Histories Project is funded by the New Zealand Law

2 The New Zealand Association of Women Judges is the New Zealand chapter of the International Association of Women Judges <www.iawj.org>. The New Zealand Women Judges Oral Histories Project is led by a committee co-convened by Dame Judith Potter and Dame Susan Glazebrook. The other committee members are Judge Rosemary Riddell, Judge Dale Clarkson and Judge Somerville. See an update of the Oral Histories Project in Susan Glazebrook "Voices of New Zealand's Women Judges: Oral History Project" (2013) 25 Oral History in New Zealand 17. 
Foundation and the Ministry of Culture and Heritage. ${ }^{3}$ The project will record life history interviews exploring the lives and careers of selected senior and retired women judges. ${ }^{4}$

The interviews conducted as part of the project will form a record available for researchers held at the Alexander Turnbull Oral History Centre. ${ }^{5}$ Each interview will be accompanied by a recording agreement form, an abstract (detailed contents summary), a transcript of the interview and photographs (as appropriate).

\section{B Methodology of the Oral Histories Project}

There will be 18 interviews as part of the Oral Histories Project. ${ }^{6}$ The majority of these interviews has been, and will be, conducted by an experienced oral historian, Megan Hutching. Nine biographical papers, based on the interview transcripts, have been written by judge's clerks. ${ }^{7}$ Each paper covers broad themes emerging from the interviews. The structure of these papers generally follows each judge's childhood, schooling, law school experience, career and work experience, community involvement, judicial experience and reflections on her life to date. These biographical papers also draw information from other publicly available information about each judge, for example, articles and speeches written by, or about, the particular judge, and newspaper and magazine articles.

The nine biographical papers written to date involve these women judges: Dame Augusta Wallace (Magistrates' Court, now deceased); Dame Judith Potter (High Court, retired); Justice Lowell Goddard (High Court); Judge Carolyn Henwood (District Court and Youth Court, retired); Judge Shonagh Kenderdine (Environment Court, retired); Judge Annis Somerville (Family Court); Judge Stephanie Milroy (Waitangi Tribunal and Māori Land Court); Judge Carrie Wainwright

3 The Ministry of Culture and Heritage funding covers interviews of five judges of Māori heritage or who have worked extensively with Māori. These judges are: Judge Somerville, Judge Wainwright, Justice Goddard, Judge Fox and Judge Milroy.

4 The 18 women judges participating in the Oral Histories Project are listed on pages $409-410$ and in footnote 8 of this article. The women judges come from all levels of New Zealand's courts and tribunals. As can be seen in this paper, the women judges also have varied interests and backgrounds.

5 There may be time embargoes on the oral histories, which may not be accessible during the lifetime of a judge or while she is still sitting as a judge. Permission will be required for access to the oral histories.

6 The project's funding covers 12 interviews. The 13th interview is with Dame Augusta Wallace. The interview was conducted by a family connection before her death and has been made available as part of the New Zealand Women Judges Oral Histories Project.

7 Two of the nine biographical papers prepared to date were written by former Court of Appeal clerk, Yasmin Moinfar, and the rest have been written by the author. 
(Waitangi Tribunal, Māori Land Court and District Court); and Judge Caren Fox (Waitangi Tribunal, Māori Land Court and Alternate Judge of the Environment Court). ${ }^{8}$

\section{Objectives of the Oral Histories Project}

There are three related aims in the part of the project which is funded by the New Zealand Law Foundation: ${ }^{9}$

(a) to record and assess women judges' experience of, and perspectives on, the law and judging;

(b) to provide insight into the varied careers of New Zealand's women judges and their contributions to the legal profession and the judiciary, both in New Zealand and internationally; and

(c) to contribute to an understanding of the relatively low levels of participation of women in the legal profession and the judiciary.

For the Ministry of Culture and Heritage part of the project, there is the added aim of contributing Māori perspectives on the above matters.

\section{THE VALUE OF ORAL HISTORY}

Before telling the stories emerging from the Oral Histories Project, it is useful to explain what oral history is, what value it provides as a source of historical record and its limitations as a source of historical record.

\section{A What is Oral History?}

Donald R Richie describes oral history as a method for collecting "memories and personal commentaries of historical significance through recorded interviews". ${ }^{10}$ The women judges participating in the Oral Histories Project have generously shared their personal insights into the law and judging through recorded interviews. Their insights are important because they add the view of eyewitnesses to existing records, providing new or additional information about the history of women's participation in legal education and the legal profession. ${ }^{11}$ As explained by New Zealand

8 Biographical papers have yet to be written based on the interviews of Dame Susan Glazebrook, Judge Coral Shaw, Master Anne Gambrill, Judge Dale Clarkson, Judge Jan-Marie Doogue, Justice Marion Frater, Justice Ellen France, Justice Helen Winkelmann and Judge Denise Clark.

9 These objectives are discussed more fully in Glazebrook, above n 2, at 17-18.

10 Donald A Richie Doing Oral History: A Practical Guide (Oxford University Press, New York, 2003) at 19.

11 New Zealand History Online "A guide to recording oral history" <www.nzhistory.net.nz>. 
History Online, the purpose of oral history is not to repeat what has been written and recorded about the past: ${ }^{12}$

Instead it gives us the personal perceptions of individuals who were there, so we can learn not only

what happened to people in the past but also the thoughts and feelings they recall having at that time.

In the Oral Histories Project, the women judges' stories "give context to the statistics showing that women's participation in the highest levels of the legal profession remains the exception rather than the norm". ${ }^{13}$ As Dame Susan Glazebrook has documented, despite the fact that over the past 20 years the number of women law graduates has been equal to, and even greater than, the number of men, the percentage of women judges in New Zealand remains slightly below 28 per cent. ${ }^{14}$ The judges interviewed in this project form part of this minority of the judiciary who are women. Their stories, detailed in Part IV, provide a snapshot of the challenges these women judges faced in breaking into this male-dominated institution.

\section{B Making Room for the Stories of Women in the Law}

The achievements of women in entering and succeeding in the judiciary do not mean that their voices are heard equally as strongly as those of their male counterparts. Thus, a second important value of oral history is that it can give voice to stories that are never heard and therefore lost; in particular, it gives voice to people who are often "left out of historical records". ${ }^{15}$ Professor Kim Rubenstein and Holly Kerwin explain that in the legal profession, which has been "exceptionally dominated by men, women's stories of leadership and pioneering, although remarkable, have been forgone for easier stories". ${ }^{16}$ They observe that feminist historiography has established that "in a world of mythmaking dominated by men, the agency of women is often unnoticed or unreported". ${ }^{17}$

12 New Zealand History Online, above n 11.

13 Glazebrook, above n 2, at 19.

14 Glazebrook, above n 2, at 18, citing Jane Glover "Women on the Bench" (2010) 134 NZ Lawyer; and Human Rights Commission New Zealand Census of Women's Participation 2012 (November 2012, Wellington) at 72. The statistics of the United Kingdom Judicial Appointments Committee shows that in 2012/2013, women had, for the first time, been recommended for more judicial posts than men. For posts requiring legal qualifications, women represented 44 per cent of applicants and 52 per cent of recommendations: United Kingdom Judicial Appointments Commission Annual Report and Accounts 2012/2013: Modernising Judicial Selection (The Stationery Office, London, 2013) at 15.

15 New Zealand History Online, above n 11.

16 Hollie Kerwin and Kim Rubenstein "Reading the Life Narrative of Valerie French, the First Woman to Sign the Western Australian Bar Roll" in Founders, Firsts and Feminists: Women Leaders in Twentieth-century Australia (eScholarship Research Centre, Melbourne, 2011) 172 at 175.

17 At 175 
Further, although women trailblazers may be well known in their particular fields, they may not be well known figures in any written record. ${ }^{18}$

Women have been very successful in reaching many of the top legal positions in New Zealand. At the time of writing, four Heads of Bench are female: Chief Justice Sian Elias, President of the Court of Appeal Ellen France, Chief High Court Judge Helen Winkelmann, and Chief District Court Judge Jan-Marie Doogue. However, these women's successes in top legal roles remain exceptional. Of 32 Attorneys-General in New Zealand, Professor Margaret Wilson remains the first and only female Attorney-General. Of 12 Chief Justices of New Zealand, Dame Sian Elias is the first and only female Chief Justice. Of 20 Governors-General of New Zealand, two have been women: Dame Catherine Tizard and Dame Silvia Cartwright. Of 10 Solicitors-General of New Zealand, none have been women.

Of the 278 QCs appointed since the establishment of this rank in 1907, 21 are women (as of June 2014). ${ }^{19}$ Behind this particular statistic is the fact that not only do women constitute a minority of barristers in New Zealand (36 per cent) and therefore form a smaller pool of eligible women for QC rank compared with eligible men, there are disproportionately low numbers of women applying for QC rank compared with men (out of 116 applications for QC status last year, only 16 were women) ${ }^{20}$ The most recent round of QC appointments has given more cause for hope, however out of 14 new QC appointments in June 2014, a third of the appointees (four out of 14) were women. ${ }^{21}$ Nevertheless, as Christine Grice, the Executive Director of the New Zealand Law Society has commented, the relatively low representation of women in New Zealand's highest rank for lawyers indicates that the "trickle up" effect is not happening - the large number of women graduating with law degrees is not translating into the equal representation of women and men in positions of leadership in the legal profession. ${ }^{22}$

The above snapshot of the proportion of women in leadership in the legal profession demonstrates how women's participation in the highest levels of the legal profession remains remarkable. This makes the record of the stories of women judges even more important, to ensure that the development of legal history incorporates the stories of both men and women.

18 At 175

19 As calculated by the author, based on the Crown Law Office's list of Queen's Counsel appointments since 1907 as at July 2013, plus the Queen's Counsel appointed in June 2014.

20 Laura Dooney "Low number of women applying for Queen's Counsel" (5 February 2014) Newstalk ZB <www.newstalkzb.co.nz>.

21 Christopher Finlayson "Queen's Counsel appointed" (press release, 5 June 2014).

22 Radio New Zealand "Gender Imbalance in the Law" (10 March 2014) <www.radionz.co.nz>. For a transcript of the interview, see "Gender Imbalance in the Law" (2014) 45 VUWLR 453. 


\section{The Value of Judicial Biography}

One might ask of the Oral Histories Project, why focus on judges? Some oral history projects, such as the Australian Trailblazing Women and the Law Project, ${ }^{23}$ involve women in the legal profession in a much wider sense, including lawyers in private practice and public service, judges, legal researchers and academics. ${ }^{24}$ The Oral Histories Project in New Zealand has a narrower scope, in part because the initiator of the project is the New Zealand Association of Women Judges and perhaps also because of limitations in funding. Although a project capturing a wider group of interviewees is desirable, there is value in focusing on the oral history of judges in particular, for four reasons.

The first reason why judicial biography is valuable is that appointment to the bench is a relatively robust method of identifying merit and success in a legal career. This is relevant given that one of the objectives of the Oral Histories Project is to understand the factors for women's success in the law. Appointment to the judiciary is one means (but not the only means) of identifying those who have achieved success in the legal profession, regardless of gender. The "bare minimum" requirement under s 6 of the Judicature Act 1908 is that a judge has had a practising certificate for at least seven years. But as the Courts of New Zealand government website says, judges require much more than just experience in practice. They must have not only sound knowledge of the law but also a "sense of what justice means and requires in present-day New Zealand". ${ }^{25}$ They must also have "discipline, capacity and insight to act impartially, independently and fairly". ${ }^{26}$ Given that judges must excel technically in the law, as well as demonstrate integrity and leadership, they form an ideal group of people for study in an oral histories project.

Secondly, judicial biography is distinct from other forms of biography because of the ability to reflect on how judges' upbringing and life experiences have shaped their decision making as judges. This influence of judges' background on their judicial decision making was an important topic during the proceedings for Justice Sonia Sotomayor's confirmation to the United States Supreme Court. As American judicial biographer Jeffrey Toobin commented, Justice Sotomayor "embraced

23 Australian National University and the University of Melbourne "The Trailblazing Women and the Law Project" <www.tbwl.ersc.unimelb.edu.au>. The author assisted with this project as an ANU summer research scholar, assisting Professor Kim Rubenstein and Dr Heather Roberts in the summer of 2009/2010. The author's research contributed to an article on Justice Valerie French: see Kerwin and Rubenstein, above n 16.

24 Kerwin and Rubenstein, above n 16, at 174.

25 Courts of New Zealand "Judicial Appointments" <www.courtsofnz.govt.nz>.

26 Courts of New Zealand, above n 25. 
the view that women and minorities brought something different to the bench". ${ }^{27}$ In several speeches, Justice Sotomayor had commented that her experiences as a woman and as a Hispanic had some influence on her decision making. She said that impartiality was an aspiration, rather than a fact, because people's experiences led them to make different decisions than those with different experiences. In particular, she said that personal experiences affected the facts that judges chose to see. Perhaps most controversial was her "wise Latina" comment: ${ }^{28}$

I would hope that a wise Latina woman with the richness of her experiences would more often than not reach a better conclusion than a white male who has not lived that life.

Although Justice Sotomayor later resiled somewhat from her "wise Latina" comment (dismissing it as merely a "rhetorical flourish"), ${ }^{29}$ the important point for the purposes of judicial biography is that judges' personal experiences do have some influence on their decision making.

In focusing on women judges, the Oral Histories Project may shed some light on whether women judges do perceive that their gender (among other factors) may lead them to reason differently from male judges. It is necessary to acknowledge the gendered assumptions implicit in the concept of "difference". In asking whether women judges make a difference in comparison with men, this inquiry implicitly assumes that men and masculine approaches to judging are the norm. ${ }^{30}$ This assumption can be problematic by suggesting that the views of men are "normal" and that the views of women are not. ${ }^{31} \mathrm{I}$ argue that although it is necessary to acknowledge this gendered assumption, the comparison of women's and men's experiences can still be a useful inquiry. In asking how a more gender-balanced judiciary makes a difference to an institution dominated by men, I wish to highlight that a judiciary that produces decisions shaped only by men's experiences is not neutral. A judiciary that seeks to apply notions of justice broadly shared by the community today needs to reflect the viewpoints and values of an increasingly diverse society. And as the Chief

27 Jeffrey Toobin The Oath: The Obama White House and the Supreme Court (Doubleday, New York, 2012) at $134-135$.

28 Toobin, above n 27, at 135 .

29 Toobin, above $\mathrm{n} 27$, at 140.

30 Clare McGlynn The Woman Lawyer: Making the Difference (Butterworths, London, 1998) at 185, citing Regina Graycar "The Gender of Judgments: An Introduction" in Margaret Thornton (ed) Public and Private - Feminist Legal Debates (Oxford University Press, Oxford, 1995) at 262-282.

31 McGlynn, above n 30, at 195. 
Justice of Canada, the Rt Hon Beverley McLachlin has said, gender diverse benches symbolise a society's commitment to gender equality. ${ }^{32}$

A conscious commitment to understanding women's contribution to the judiciary raises the interesting question of whether a distinct female approach to judging exists. The answer appears to be no. In a review of relevant literature, Erica Rackely found that "attempts to identify difference in the commentary and judgments of female judges have been inconclusive and controversial". ${ }^{33}$ Although it may seem intuitive that women do judge differently from men, the search for a distinct female judicial voice has proved elusive. ${ }^{34}$

Even in the absence of a coherent female judicial voice, it is problematic that certain areas of the law which affect women particularly have historically developed without meaningful reference to women's perspectives. As Justice Bertha Wilson, the first woman judge of the Supreme Court of Canada, has observed, although there are probably "whole areas of the law on which there is no uniquely feminine perspective", there are certain areas of the law where a "distinctly male perspective is clearly discernible", and which has "resulted in principles that are not fundamentally sound and should be revisited as and when the opportunity presents itself". ${ }^{35}$ As an example, Justice Wilson said that some aspects of the criminal law "cr[ied] out for change because they [were] based on presuppositions about the nature of women and women's sexuality that in this day and age [were] little short of ludicrous". ${ }^{36}$

The idea of, and indeed the need for, feminist judicial practice has been explored by feminist judgment writing projects in Australia, ${ }^{37} \mathrm{Canada}^{38}$ and the United Kingdom. ${ }^{39}$ Broadly speaking,

32 A summary of Chief Justice McLachlin's speech is provided in Mary-Ann Hedlund and Susan Glazebrook "Foreward" in Mary-Ann Hedlund, Susan Glazebrook, Arline Pacht and Jill Wainwright (eds) The IAWJ: Twenty Years of Judging for Equality (International Association of Women Judges, 2010) at 3.

33 Erica Rackley "Detailing Judicial Difference" (2009) 17 Fem Leg Stud 11 at 14. See also Dermot Feenan "Editorial Introduction: Women and Judging" (2009) 17 Fem Leg Stud 1 at 4.

34 Rackley, above n 33, at 14.

35 Bertha Wilson "Will Women Judges Really Make a Difference? The Fourth Annual Betcherman Memorial Lecture" (1992) 30 Family and Conciliation Courts Review 13 at 19.

36 At 19. This Special Issue of the Victoria University of Wellington Law Review contains several excellent articles providing feminist critiques of New Zealand law.

37 University of Queensland "Australian Feminist Judgments Project" <www.law.uq.edu.au>.

38 The Women's Court of Canada <www.womenscourt.ca〉.

39 University of Kent "Feminist Judgments Project" <http://www.kent.ac.uk>; and Rosemary Hunter, Clare McGlynn and Erika Rackley (eds) Feminist Judgments: From Theory to Practice (Hart Publishing, Oxford, 2010). 
these projects have involved selecting cases affecting feminist principles in substantive areas of law (for example, as regards gender equality, family law and the use of evidence in criminal trials) and rewriting these judgments in a way that highlights unarticulated gender biases in the actual judgments, and consciously reflects women's lives and experiences. This is not to say, of course, that all, or even most, women judges necessarily self-identify as feminists ${ }^{40}$ (or that men do not identify as feminists), but what this research shows is that the consideration of the experiences of women does make a difference in judging, and does challenge the notion that the development of the common law is based on neutral, gender-blind assumptions.

Beyond the outcome of case decisions, the presence of women can also impact on the judiciary internally (ie in the way the judiciary operates), as well externally (ie the way the judiciary is represented to, and perceived by, the wider legal profession and the public). ${ }^{41}$ As regards changes internal to the judiciary, Elaine Martin's study of women appointed to the United States federal bench by President Jimmy Carter is instructive. In Martin's study, most of the women judges felt that their judicial decisions were not that much different from those of male judges, but thought that their presence did change judicial behaviour in subtle ways. ${ }^{42}$ Specific examples included perceptions that sexist language was no longer used (or not used as much) in chambers or in the courtroom, as well as the employment of more women law clerks. ${ }^{43}$

The extra-curial work of women judges also impacts on the external representation of the judiciary as an institution that is progressive on gender issues. ${ }^{44}$ The New Zealand Association of Women Judges, for example, has raised the profile of women judges, not just through the Oral Histories Project, but also through events such as hosting an Asia-Pacific regional conference for women judges in Auckland in 2013. Dermot Feenan has observed that women judges in the United States have been instrumental in setting up state and federal taskforces to examine gender bias in courts. $^{45}$

Moving back to the main subject of why judges make ideal study subjects, the third reason for focusing on judges in this Oral Histories Project is because there is often a great deal of publicly

40 For further reading, see Beverley Baines "Must Feminist Judges Self-identify as Feminists?" in Ulrike Schultz and Gisela Shaw (eds) Gender and Judging (Hart Publishing, Oregon, 2013) 379.

41 Elaine Martin "US Women Federal Court Judges Appointed by President Carter" (2009) 17 Fem Leg Stud 43 at 55 .

42 At 55.

43 At 55 .

44 Feenan, above n 33, at 6.

45 Feenan, above n 33, at 6. 
accessible information about judges, most notably their judgments, but also their extrajudicial speeches, papers and activities in the community. The availability of this information makes it possible to create a more comprehensive study of the interviewed person's life. This issue was addressed in a panel discussion hosted by the London School of Economics on judicial biography. Panel member Professor Neil Duxbury said that the law is not a science, and when one begins to understand what judges' backgrounds and education are, their decisions "begin to make sense". He said that judges, like all people, are shaped by many different factors, including historical forces (for example, an event like World War Two), intangible structures (for example, gender, class and religion) and more concrete institutions (such as the legal profession, family and friends). ${ }^{46}$ Professor Lisa Jardine added, in the same panel discussion, that humans desire to make sense of someone who has made an important impact on society, and this explains why biographers seek recourse to judges' lives to seek answers. She posits that "it is a fundamental part of the human condition to desire to produce causality between the life and outcomes of that life in work". ${ }^{47}$

Finally, the value of judicial biography has particular relevance in New Zealand in creating a treasure trove of information about judges from which more detailed judicial biographies may be written. It is beyond the scope of this article to attempt to draw concrete links between the interviewed judges' backgrounds and their judicial work. This would be the work of more detailed research. Although such research is uncommon in New Zealand, it is popular especially in the United States. For example, in The Oath, Jeffrey Toobin draws on interviews with the judges of the United States Supreme Court and over 40 of their law clerks to assess the political leanings of each of the Supreme Court justices. ${ }^{48}$ By way of illustration, Toobin tracks Justice Ruth Bader Ginsburg's legal practice in advancing gender equality in the law through several cases at the United States Supreme Court - a commitment to gender equality that became important in her decisions as a judge, including on abortion issues. ${ }^{49}$

\section{The Use of Oral History Interviews in Constructing History}

Having established the usefulness of oral history interviews in providing first-hand perspectives on historical events, it is helpful to assess their limitations as a source of historical evidence. An awareness of the limitations of oral history would avoid a potential misconception that oral history

46 Neil Duxbury, Professor of Law "Panel Discussion on Judicial Biography: LSE Law Department's Legal Biography Project Sponsored by Clifford Chance" (Hong Kong Theatre, Clement House, 17 October 2007).

47 Lisa Jardine, Professor of Renaissance Studies and Director of the Centre for Editing Lives and Letters "Panel Discussion on Judicial Biography: LSE Law Department's Legal Biography Project Sponsored by Clifford Chance" (Hong Kong Theatre, Clement House, 17 October 2007).

48 Jeffrey Toobin, above n 27. See also Michiko Kakutani "9 Justices Who Sit in the Eye of Storms" The New York Times (online ed, 22 October 2012).

49 Toobin, above n 27, at 61-62 and 67-68. 
interviews represent complete records of past events. ${ }^{50}$ Rather, oral history interviews are a rich source of information on which understandings of the past may be developed; thus oral history interviewing is part of the process of making history. Below I discuss five points regarding the limitations in the use of interviews in this women judges' Oral Histories Project.

First, oral histories, based on human memory, have special value as subjective, spoken testimony. ${ }^{51}$ Yet the sense of immediacy felt when listening to or reading about a personal account of an event does not necessarily mean that the interviewed person's narrative of a particular moment is shared by others who also experienced the same event. ${ }^{52}$ Oral history interviews offer a personal perspective so it is important to consider potential biases arising from the interviewee's relationship to a particular event and the interviewee's personal stake in presenting a particular version of the event. $^{53}$

Secondly, the interview process necessarily impacts on (and potentially constrains) the way interviewees tell particular stories, and in a broader sense, affects the way they make sense of the experiences in their lives. There are time constraints in life history interviews: an interviewee must compress "years of living into a few hours of talk, selecting, consciously and unconsciously, what to say and how to say it". ${ }^{44}$ There are also constraints imposed by the relationship between an interviewer and an interviewee, and the goals of the particular oral history project of which the interview forms a part. This is because each interview is a "response to a particular person [the interviewer] and set of questions, as well as to the narrator's inner need to make sense of an experience". ${ }^{55}$ Not only does the interview process itself impose certain constraints in the way the interviewees tell their stories, another layer of interpretation is added when a researcher (like the author of this article) selects particular anecdotes from the oral histories and tries to construct a theme from these anecdotes.

Thirdly, there is a deliberately gendered dimension in the Oral Histories Project. The fact that the Oral Histories Project is run by the New Zealand Association of Women Judges and is

50 Judith Moyer "Step-by-Step Guide to Oral History" (1999) Do History <www.dohistory.org>.

51 Marietjie Oelofse "Applying Principles of Historical Critique: Authentic Oral History?" (2011) 5 IPEDR 41 at 42 .

52 History Matters "Interpreting Oral History" <www.historymatters.gmu.edu>. See also Michael Frisch $A$ Shared Authority: Essays on the Craft and Meaning of Oral and Public History (State University of New York, Albany, 1990) at 159-160.

53 History Matters, above n 52.

54 History Matters, above n 52.

55 History Matters, above n 52. 
interviewing only women judges means that there is an emphasis on understanding the judges' life histories from a gendered perspective.

Fourthly, oral history interviews, like other forms of historical material (such as newspaper articles, textbooks and films), are susceptible to bias. Therefore, oral history interviews should be considered alongside other forms of historical evidence to build a more nuanced representation of history. ${ }^{56}$ In drafting the biographical papers based on the interviews of each judge, attempts have been made to corroborate factual aspects of the interviews by using publicly available information to confirm or correct the statements made in the interviews. ${ }^{57}$ Corroboration can also occur in oral history projects like the Oral Histories Project by interviewing a sufficiently large group of people. A larger body of interviews with women alive during roughly the same time period means that the perspectives of different judges about the same events can be used to construct a more complete record of historical events and to provide diverse perspectives on how people experienced the same events.

Finally, it is emphasised that the stories in this article reveal each judge's personal experiences. The judges come from many different backgrounds and pursued their legal studies and careers at different times. Their experiences do not necessarily reflect the experiences of women in the law in a general sense. Nevertheless, the stories below provide snapshots of the experiences of women pioneers in the law and also contribute personal perspectives on women's participation in the law published for the first time.

\section{STORIES FROM THE ORAL HISTORIES PROJECT}

In light of the background to oral history set out above, the stories about the challenges faced by nine women judges are told in the following two sections. The stories in this first section detail the challenges these women faced as a result of their gender and demonstrate how they broke gender barriers at various stages of their legal education and careers. The second section adds a Māori dimension to the challenges faced by the women judges discussed in the first section. Specifically, this section focuses on the interviews with three women judges: Judge Milroy, Judge Fox and Judge Wainwright. ${ }^{58}$ The experiences of Judge Milroy and Judge Fox as Māori women entering a

56 Oelofse, above n 51, at 42 .

57 For example, newspapers contemporary with events mentioned in the interviews were used to confirm the dates mentioned by interviewees in their interviews.

58 The author has chosen to focus on the stories of these three judges because the content covered in their interviews provided relevant comparisons given the focus and length of this article. Other Māori judges, or judges with extensive involvement in te ao Māori, were also interviewed, but space did not permit more detailed discussion of their experiences. 
predominantly Pakeha legal world are contrasted with the experiences of Judge Wainwright as a Pakeha woman entering te ao Māori.

Although the focus of this article is on the experiences of New Zealand women judges, the challenges that they faced resonate with the stories of pioneering women lawyers the world over. There is already much existing literature on the experiences of women in the law around the world. ${ }^{59}$ It is hoped that the stories shared here will connect New Zealand women lawyers to the global struggle for women to be taken seriously as legal professionals.

\section{A Overcoming Challenges as Women Trailblazers in the Law}

At every step of their life in the law, the women judges interviewed broke new ground. Their successes created new norms that established women's entry into the highest levels of the legal profession. This section considers the way particular women judges broke gender barriers at different points in their life: at law school, in their early careers, through creating support networks for women, by joining male-dominated district and national law society councils, and as women judges respectively.

\section{Breaking gender barriers at law school}

It is extraordinary for young people today (and the author is a recent law graduate) to imagine that not so long ago, women were a minority of students at law school. The women judges' decisions to go to law school were sometimes questioned because they did not reflect the stereotype that women were better suited to employment as teachers or nurses. For example, Dame Augusta Wallace, the first female magistrate in New Zealand, said that despite the fact she came from a legal family (her father was a lawyer), a neighbour had told Dame Augusta's mother that it was a "waste of money sending [Dame Augusta] to university -she would be far better learning to be a nurse or a teacher".

In her interview, Dame Judith Potter commented on how her father's complete support for her decision to go to law school was a rare reaction in those days. Her mother had been supportive too

59 For global comparative perspectives, see Mary Jane Mossman (ed) The First Women Lawyers: A Comparative Study of Gender, Law and the Legal Professions (Hart Publishing, Oxford, 2006); and Ulrike Schultz and Gisela Shaw (eds) Women in the World's Legal Professions (Hart Publishing, Oregon, 2003). For literature from the United Kingdom, see Hilary Sommerlad and Peter Sanderson Gender, Choice and Commitment: Women Solicitors in England and Wales and the Struggle for Equal Status (Dartmouth Publishing, England, 1998); Clare McGlynn The Women Lawyer: Making the Difference (Reed Elsevier (UK) Ltd, London, 1998); and Penny Darbyshire Sitting in Judgment: The Working Lives of Judges (Hart Publishing, Oregon, 2011) (the Darbyshire text is not limited to women judges). For literature from Australia, see Margaret Thornton Dissonance and Distrust: Women in the Legal Profession (Oxford University Press, 1996). 
but was a little troubled by her daughter's decision. Dame Judith recalled how one of her mother's friends had said:

Why does Judith want to do law? Judith seemed quite a nice girl, and surely Judith would get married, and wouldn't it be a total waste of time for Judith to do law?

At the time that Dame Judith went to law school, there were perhaps half a dozen other women there. When she graduated in 1965, she and Elizabeth Wright were the first two women in any year to graduate from the University of Auckland Law School (there were more than 200 graduates that year). In a 1988 interview, Dame Judith recalled how, "When I was at law school some lecturers would start [lectures by addressing the students as] 'Gentleman, Miss Potter and Miss Wright."'60

When Justice Goddard ${ }^{61}$ went to university, there were at that time only a handful of women at law school. Her contemporaries included Professor Margaret Wilson and Chief Justice Sian Elias. She remembered that the lecturers were very supportive and did not generally show any sexist attitudes towards the female students. However, she remembered that the men in her class gave the only two women lecturers quite a hard time. She also thought that having men and women in the same class was a novelty for both men and women (and not just women) because few of the students would have gone to co-educational high schools.

Despite a generally supportive environment at law school, Justice Goddard recalled specific examples of gender discrimination, including the annual law school dinner:

There was a law school dinner every year, which was a black tie affair, and women just were not invited to it. So in my second or third year the female students were there, Margaret Wilson, Sian Elias and myself, we went along to the dinner. Nobody said we couldn't go, it was just sort of a given that we weren't included and how would we cope because people drank too much and probably uttered profanities and told off-jokes and the speeches were probably completely centred around female anatomy and things like that. Anyway we went along and that did a lot to break the ice.

Justice Goddard described the reaction as:

... I think [the reaction] was surprise that everybody still had a good time even though there were girls there. We didn't actually spoil the fun. You could actually have fun without descending to rugby shed humour and vulgarity and total drunkenness and I think it was a very civilising influence. It's a very civilising influence having women involved in anything and everything.

60 "Women in the Law (II)" [1988] NZLJ 148 at 148.

61 Justice Goddard had iwi affiliations on her father's side to Ngāti Kahungungu in the main and also Te Aitanga-a-Mahaki and Tūhoe. 
Once Justice Goddard had been to the law dinner, she and her female classmates continued to break other gender barriers:

I went to everything. I made a point of going to everything. That's the way to do it. It's called normalising but it was the same with early life on the bench and early years in practice. I can remember a practitioner saying to me when I first went out as a barrister, "Yes, but how could you do a case about commercial this or that, you wouldn't know about these things." Well, nobody is born knowing about these things are they? The same as going to the bench." Oh, but how will women judges deal with high powered commercial litigation?" Well, actually extremely well. Of course it is now normal to see a female on the bench dealing with things. Nobody thinks twice about it. They don't think, "Oh my Lord, a woman judge. She won't understand."

\section{Breaking gender barriers in their early careers}

This section examines a common theme arising from some of the interviews that the discrimination experienced by women did not necessarily take the form of overt bias against women. Sometimes men's attitudes towards women were demonstrated through off-hand comments or simply a failure to see women in leadership as a possibility. For example, Judge Somerville ${ }^{62}$ recalled how she was bringing in a lot of money for a firm that she was working for. One of the male partners said to her, "When your children are grown up, you might become a partner." Judge Somerville was rather indignant at the suggestion that she could only become a partner after her children had grown up. She ultimately decided to start her own firm.

Another example is Judge Henwood, who asked to be made partner at the firm where she worked. When asked in the interview about why she wanted to become a partner, she replied, "Well, if you're working 24/7 and doing equal work, you want to be a partner, don't you?" She had made up her mind to ask for partnership one night when she attended a function hosted by a bank, where she was the only female among many men. There were no women in banks at the time unless the employee was a teller. She asked one of the male partners about the possibility of partnership. The male partner was startled because the possibility of a female partner had never occurred to him. He said, "I had never thought of that. Goodness." Initially the firm rejected her request for partnership but then later offered it to her. The firm's partners said that they did not realise that she had wanted partnership. Her response was, "Why wouldn't I? What's different about me?"

Judge Wainwright also recalled how seemingly gender-neutral practices at her firm in fact had a negative impact on women. At one time, there were five women partners at the firm but each left the partnership to have children. Judge Wainwright battled with the firm over maternity leave and the terms on which she could become a part-time partner. When she had her first child, she had four

62 Judge Somerville is affiliated with Ngāi Tahu. 
months' maternity leave and returned afterwards on the basis that she would work 60 per cent of the time for six months and be remunerated at 60 per cent of a full partner. By the time she had her second child, the firm had changed its tune. One of the male partners of the firm put it to the Board of the firm that if a partner wanted to work less than 100 per cent of the time, he or she had to cease being a partner. If that path were chosen, the person could be re-voted by the Board to become a partner. The motion was presented as not being to do with women specifically, but as a matter of principle that you had to be a full-time partner or not at all. Although Judge Wainwright in fact succeeded in getting the firm to allow her to be a part-time partner again for a short period, she did not think that her success made much of a difference for the women in her firm in the long-term.

Although there were several examples where men had showed sexist attitudes, there were many other examples where men were some of the greatest supporters of the women judges in their early careers. Judge Kenderdine spoke of the significance of the work of the former Deputy SolicitorGeneral, Craig Thompson, in recruiting both junior and senior women counsel to the Crown Law Office, which had previously been an all-male domain. Many of those women have gone on to become QCs and judges. Judge Kenderdine counted her own progress through to the judiciary as a result of the work she undertook in Crown Law as head of the Treaty of Waitangi team. She explained too that her appointment as a Planning Judge (which became the Environment Court) was due to the encouragement of Rt Hon Sir Peter Blanchard and Mr Antony Hearn QC.

Justice Goddard also explained that when Justice John McGrath was Solicitor-General, he had actively encouraged her to become his Deputy Solicitor-General and lead the Crown Law Office's criminal team. She also thought that she would not have gone on to apply to be a QC without support from some senior members of the judiciary, in particular Lord Cooke, who thought it was timely and appropriate for a woman to be appointed as QC. Justice Goddard, along with Chief Justice Elias, ultimately became the first women in New Zealand to be appointed QCs.

\section{Breaking barriers through creating support networks for women}

Another sub-theme arising from the interviews is the way in which women formed networks of support to help each other both in New Zealand and internationally. Two particular examples stand out: the establishment of the Otago Women Lawyers' Society (OWLS) in New Zealand, and first international women judges' conference in 1993.

(a) Otago Women Lawyers' Society

The establishment of the Otago Women Lawyers' Society (OWLS) in 1986 is an example of how some women used networks to support each other and to teach women skills to help them to succeed in their legal careers. Sister organisations were established in Auckland ${ }^{63}$ and Wellington ${ }^{64}$

63 Auckland Women Lawyers' Association <www.awla.org.nz〉. 
in 1984 and 1987 respectively. Judge Somerville explains that one of the reasons for starting OWLS was to teach women to dress professionally. Although "power dressing" may seem obvious to many women lawyers now, Judge Somerville remembered that women did not used to know how to dress formally for court. She recalled how one woman was called up to a judge's chambers because she was wearing harem pants and was told they were not suitable for court. As Judge Somerville put it, "These were the days before you knew how to power dress, [before] you knew how to make an impression."

It is interesting how dress has long been symbolic of women's struggle to be taken seriously. New Zealand's first woman lawyer, Ethel Benjamin, herself a practitioner in Dunedin, faced ridicule when a cartoon in the Exhibition Sketcher depicted her having problems with her court attire. In the cartoon, Ms Benjamin is dressed in a barrister's gown, putting on her wig and worrying about whether her petticoat is visible below her gown. ${ }^{65}$ She is shown as saying, "Oh heavens, where are my wig pins! Now my brief. Does my jupon show below my gown? Right now for court!" Even today, the issue of dress and courtroom appearance continues to have important significance not just for women lawyers, but also women judges. Overseas research has shown, for example, that some women judges consciously consider how they dress, specifically "whether to dress in a way that signals femininity or to veil it". 66

Returning to Judge Somerville's story before OWLS was formally constituted, it was simply a group of women lawyers who used to meet for lunch and provide each other with support. The group decided to call themselves OWLS because the owl was a symbol of wisdom. The establishment of OWLS caused a huge amount of concern amongst some men. The OWLS women would walk down the street and occasionally men would hoot at them and some asked to join the society.

Judge Somerville explains how OWLS also played an important role in ensuring that women were represented on the Otago Law Society council. At the time, there were no women on the Law Society council. Women did not have any voice and were not considered to be of particular value. They were being employed as lawyers but often pigeonholed into family law. They were not being given valuable work, they were not being mentored and they were not being shown what to do. They were "dumped in it at court". Women were often given cases of little value so they rarely became partners.

64 Wellington Women Lawyers' Association <www.wwla.org.nz>.

65 Mossman, above n 59, at 171.

66 Ulrike Schultz and Gisela Shaw "Introduction: Gender and Judging: Overview and Synthesis" in Ulrike Schultz and Gisela Shaw (eds) Gender and Judging (Hart Publishing Ltd, United Kingdom, 2013) 3 at 30. 
OWLS slowly but surely became a part of the Otago Law Society's council meetings. Initially, the women asked if one of their members could observe the council meetings because the meetings were "a closed shop and no one knew what went on. It was just this group of men meeting and making decisions." The council reluctantly allowed OWLS members to come and observe. OWLS sent a different woman along to each meeting. This meant that the women were able to know what happened in the meetings and eventually they stood for council and became members in their own right. In the early days, OWLS' members stood for council and did not get elected. Some time later, the first woman got on when an election was not necessary. Judge Somerville later became the first woman to be elected to the council on the basis of very few votes. But the number of votes in support of her grew in the next round of elections when she was an established member of the council.

Sitting on the council was an interesting experience because the women realised they did not know how to make their voices heard. So OWLS organised lunches and put on sessions for women to learn to speak up. The OWLS committee also realised that it did not have anyone who had experience chairing a meeting. If a woman held a position of importance, it was usually as the treasurer of the local parent-teacher association. So the women taught themselves how to run meetings. As Judge Somerville said, the training was very basic. But it gave the women the change to learn important advocacy skills.

(b) International conference of women judges

Conferences that brought women together were also an effective strategy for promoting women's advancement in the law. In her interview, Judge Henwood emphasised the power of international conferences in particular in bringing issues relating to women to the fore and driving change for women. Judge Henwood played an important role, along with several other women judges, in organising the first international conference of women judges held in Wellington in 1993. The impetus for that conference was that 1993 marked the centenary of women's suffrage, with New Zealand leading the world in extending the right to vote to women. ${ }^{67}$ The conference participants came from 25 countries around the world. From Judge Henwood's perspective, the conference was an "absolute sensation" and she remembered how "thrilling" it was to have judges from Africa, Singapore, India, China and other countries. Judge Henwood remembers sitting with Dame Silvia, appellate court judges from Canada and other eminent women, eating kumara chips at the Polynesian Pools in Rotorua.

As a result of the conference, New Zealand became connected with the rest of the world. It was an opportunity to share knowledge about issues facing women judges around the globe. For

67 New Zealand became the first country to extend the right to vote to women on 19 September 1893: New Zealand Parliament "Women's right to vote" (22 September 2010) <www.parliament.nz>. 
example, Judge Henwood described how some women judges used international law to improve the status of women in their own countries:

If you're a woman judge and you're living in a despotic regime, you can turn to the international law to change things. Even in Korea they changed something amazing, with a tradition where women had no rights to property once they got married. ... But the women judges? I believe one of the judgments changed a custom without people realising. And that's how you can help deal with feminine issues across the world.

The 1993 conference, as well as the centenary celebration of women's suffrage, propelled the appointment of Dame Silvia as the first female High Court Judge. Given that New Zealand was the host of an international women judges' conference, it was important that New Zealand was seen to support the advancement of women in the judiciary. The appointment of Dame Silvia as New Zealand's first woman judge in a superior court was especially significant in that context.

In the wider context, the involvement of New Zealand judges in the International Association of Women Judges ultimately led to the establishment of the New Zealand chapter of the International Association.

\section{Breaking barriers by joining district and national law society councils}

This section examines how women broke barriers by joining district and national law society councils, which used to be dominated by men. It is not only the fact of these women's achievements as leaders in these legal organisations which is important, but what is also insightful is how some male members of the profession reacted to women joining a male-dominated environment. Judge Somerville's account of the initial resistance to women joining the Otago Law Society council has already discussed above.

Dame Judith served on the Auckland District Law Society council for 10 years and became its first woman president in 1988. When she was first elected to the council, there were no other women on the council or on any other law society council in New Zealand. Although most of the male members were very supportive and very keen about her joining the council, there were inadvertent comments that revealed the biases held by some of the men:

I think because they were very able practitioners, they realised that it was time that things moved on.

But I well remember the remark of a senior practitioner, who was a gentleman that I liked and admired very much, but he nearly knocked me over like a feather. He said to me, "Judith, it's really, really good that you've been elected to the council. I do congratulate you. It's terrific because, really, you're just like us." I can remember thinking, "Oh dear, that's meant to be complimentary but if he only knew what it's telling me, he would be horrified." I don't think he meant it like that, but subconsciously that's how people thought. 
Dame Judith went on to serve as the first woman president of the New Zealand Law Society ${ }^{68}$ (NZLS) from 1991 to 1994. Even in 1991, she was the only woman among the 29 members of the NZLS Council.

\section{Challenges faced as women judges}

Although the women judges generally expressed their appreciation for their male colleagues, some commented on the sense of isolation that came from being the only woman in predominantly male common rooms. Judge Somerville, for example, was the only woman in the judicial common rooms in Tauranga and Rotorua for a significant period. When she was appointed in 2001, there were no other women appointed to either the Rotorua District Court until 2007 or the Tauranga District Court until 2010. Other women judges would sit as visiting judges in Rotorua and Tauranga only occasionally. Even though she valued the companionship of the male judges, it sometimes felt isolating not to be able to draw support from other female colleagues.

Interestingly, Judge Henwood said that she became more conscious of the fact that she was a woman when she became a judge. As a woman lawyer, being female did not seem to matter so much. But the moment she became a judge, she felt that everyone scrutinised the fact that she was a woman - what she said, what she looked like and what she wore became very topical. She described the attention as extraordinary - it felt like being under a microscope. Not all the judges were welcoming of her when she was first appointed. One judge called her and advised that she should give somebody a "real hefty jail sentence" so that it would set the bar that she was going to be "tough". ${ }^{69}$ Another judge rang her and said that she should not have taken the job because it was not very good for young children and she would not be able to cope with travelling around with young children.

Judge Henwood further commented that in the judges' common room, there was a range of views about whether women should be there. Someone suggested that judges' superannuation would become limited as a result of women joining the judiciary, given the perception that women's involvement "lowered the tone of the bench". But other people were hugely welcoming and supportive. Overall, Judge Henwood described the common room as a "bit of a mixed minefield to be working in".

68 The New Zealand Law Society was established in 1869. It regulates the practice of the legal profession in New Zealand and also promotes law reform.

69 The interesting question of whether women judges do generally give more lenient sentences than male judges is discussed in Schultz and Shaw, above n 65, at 36. The authors cited studies from different jurisdictions, which did not produce a consistent answer to this question. 


\section{Gendered perspectives on judging}

This section draws together reflections that some of the women judges made about whether their gender influenced their decision making. Without wanting to over-generalise, Judge Fox thought that women brought a reflective practice to judging in a way that most men she observed did not. In Judge Fox's experience, women tended to be more accommodating of people's sensitivities in the court room so that people would feel less intimidated being in that formal space. Judge Fox also thought that women tended to think more intuitively than men and so asked questions differently, and therefore analysed legal problems differently from men. Although men and women may come to the same result in terms of the law, the way they rationalised their judgments tended to be different. Judge Fox's sentiments echo the comments made by Justice Ruth Ginsburg of the United States Supreme Court: ${ }^{70}$

There are perceptions that we have because we are women. It's a subtle influence. We can be sensitive to things that are said in draft opinions that [male justices] are not aware can be offensive.

Judge Kenderdine, who through the considerable volume of lay litigants in the Environment Court has had experience of hearing many litigants in person, also reflected on the intimidating nature of a male-dominated bench in earlier times. She saw a more inquisitorial environment now, with greater respect for all litigants and time taken to understand different points of view.

Judge Milroy considered that, in her experience, women judges did bring different experience to that of men judges. It was not necessarily that women judges made better judges but simply that they helped to "widen ... the options for everyone". Judge Milroy considered it was important for the judiciary to be representative, both of different genders and cultures. She was optimistic that more Māori judges would be appointed to the courts, not only the Māori Land Court, but also the District Court and the High Court. As the first woman British Law Lord, Baroness Brenda Hale, has said, "the incorporation of difference on the bench subtly changes and, ultimately, improves the judicial product". ${ }^{71}$

\section{B The Māori Dimension}

A specific objective of the Oral Histories Project is to understand the experiences of both women judges of Māori heritage and non-Māori who have worked extensively with Māori. This sub-part focuses on the stories of three judges of the Māori Land Court (who also sit on the Waitangi Tribunal). Judge Milroy is from Nga Tūhoe on her father's side, with Ngatikaura as her main hapū affiliation. On her mother's side, Judge Milroy is from Te Arawa, particularly Ngāti

70 Schultz and Shaw, above n 65, at 28.

71 Schultz and Shaw, above n 65, at 27. 
Whakaue and Ngāti Pikiao. Judge Fox is from Tairāwhiti and Ngati Porou, Rongowakaata, and also has whakapapa through to Te Whānau-a-Apanui. Judge Wainwright was born in Lower Hutt and through her university studies and later career became immersed in te ao Māori.

This sub-part comprises three sections. The first section examines each judge's experiences at university through a cultural lens. The second section identifies how for Judge Milroy and Judge Fox, the attainment of a legal education came with it a responsibility to use their legal skills to serve their iwi and the Māori people generally. The third section examines how the judges' cultural backgrounds influenced their judicial experiences, with a focus on their work in the Māori Land Court.

\section{Experiences at university}

(a) Judge Milroy

Judge Milroy attended Auckland law school in the late 1970s as one of only two Māori students in her year. Although there were some Māori students in the older year groups, they were just old enough to feel out of her reach. Her sense of isolation as a Māori woman (the only other Māori student in her year was male) in her first year at university made law school a "terrible, terrible struggle to get through". Later on, in her second year, Judge Milroy made friends with a group of women students with whom she formed strong bonds and law school became much more enjoyable.

Apart from the social challenges of law school, Judge Milroy found that many legal concepts were foreign to her because she had not been exposed to them in her Māori upbringing. In particular, she found it hard to relate to the individualised approach that the law seemed to take to solve problems. Responsibility lay at the door of the individual, rather than the community or the whānau. With hindsight, Judge Milroy later said that it may take Māori students some time to "recognise that in learning the law they are learning another language, another code, and this is all the more difficult because of the underlying assumptions by law teachers that there is a shared set of values and culture amongst students". ${ }^{72}$

Judge Milroy's struggles at law school spurred her to develop at the University of Waikato Law School a curriculum that would offer students a bicultural experience. ${ }^{73}$ Waikato Law School was

72 Stephanie Milroy "Waikato Law School: An Experiment in Bicultural Legal Education. Part 1: Biculturalism and the Founding of the Waikato Law School" (2005) 8 Yearbook of New Zealand Jurisprudence 173 at 192 .

73 For more detail, see Milroy, above n 72. Leah Whiu wrote Part 2 of this paper: "Part 2: The Reality of Being Māori at Waikato Law School" (2005) 8 Yearbook of New Zealand Jurisprudence 196. See also Whiu's discussion of Milroy's recommended actions for developing a bicultural vision of the Law School: Leah Whiu "Waikato Law School's Bicultural Vision - Anei Te Huarahihei Wero I A Tatou Katoa: This is the Challenge Confronting Us All" (2001) 9 Waikato L Rev 265, especially at 288-290. 
founded on the principle of biculturalism, meaning at the minimum that the Treaty of Waitangi should "stand as a blueprint for structures and processes" at the new law school. ${ }^{74}$ Judge Milroy understood biculturalism as finding ways to "live together as full human beings, in light of our history and providing for our cultural differences". ${ }^{75}$ The challenge lay in applying the concept of biculturalism to the working structures and processes of the law school. ${ }^{76} \mathrm{~A}$ bicultural law school needed at least to ensure the sharing of resources and decision making power, acknowledgement of New Zealand's bicultural history, and the establishment of practices and procedures that delivered a legal education that worked for both Māori and Pakeha. ${ }^{77}$

An example of a bicultural programme was the Baby $M$ programme, which was a week-long introduction to the study of law in context for students. ${ }^{78}$ Each aspect of this induction programme was carefully structured to make it as culturally appropriate as possible. A key focus was to create an atmosphere in which Māori students would feel less alienated. Important considerations included the choice of topic, materials, methodology and personnel in terms of biculturalism. The programme focused on the issue of surrogacy arising out of the Baby $M$ case, which was a decision of the Supreme Court of New Jersey. ${ }^{79}$ Although the Baby $M$ case was not directly relevant to Māori, the case had potential for bicultural analysis because it engaged concepts such as family, motherhood and identity which are fundamental to any culture. ${ }^{80}$ Students were encouraged to use te reo both in class discussion and in their written work. Judge Milroy considered the Baby $M$ programme to be a valuable step towards creating a bicultural learning environment, but thought that more progress would need to be made in the future.

(b) Judge Fox

When Judge Fox went to Victoria University of Wellington Law School in the 1980s, the number of Māori graduates was few but the university made earnest attempts to support Māori students. At the time, Tony Waho (now a trustee of several significant Māori language initiatives),

74 Milroy, above n 72, at 173.

75 At 184.

76 At 184 .

77 At 185

78 For further discussion, see Nan Seuffert, Stephanie Milroy and Kura Boyd "Developing and Teaching an Introduction to Law in Context: Surrogacy and Baby M" (1993) 1 Waikato L Rev 27. The first part, on "A Feminist Perspective on Teaching Law in Context", was written by Nan Seuffert (from 27). The second part, on "Biculturalism in Action?", was written by Stephanie Milroy (from 42). The third part, on a student's perspective of the Baby $M$ programme, was written by Kura Boyd (from 50).

79 In the Matter of Baby M 537 A 2d 1227, 109 NJ 396 (1998).

80 Seuffert, Milroy and Boyd, above n 78, at 43. 
Justice Joseph Williams and Ani Mikaere had created the first Māori law students' study group. The older students mentored the younger ones, and played an important role in helping Māori students to do well in their academic work and in the long-term, helped to increase the number of Māori graduates. The study group at Victoria University was later emulated at other New Zealand universities. There was an expectation on those who had benefitted from the study group to give back to the group. Judge Fox became a tutor for younger Māori students and also assisted with the development of the quota system for the admission of Māori students into law school.

Judge Fox was also instrumental in lobbying (with other Māori) for incorporating a greater degree of Māori content into the curriculum. When she started law school, there was only one lecture on the Treaty of Waitangi and one lecture on the doctrine of aboriginal title. The lobbying was successful in the introduction of more Māori subjects. Judge Fox commented that including more Māori content in the curriculum was more than about creating an environment where Māori students felt comfortable; universities had to teach Māori subjects to remain competitive because Māori jurisprudence was growing. The courts had begun to recognise Māori issues through the fisheries cases, ${ }^{81}$ as well as the cases relating to the State-Owned Enterprises Act $1986 .{ }^{82}$ Law schools were forced to accommodate these developments in the law. They had to teach Māori subjects to all students because they would be required, as lawyers, to give advice on Māori issues, even if they were not acting for Māori parties. Teaching Māori subjects gradually became part of the mainstream curriculum.

(c) Judge Wainwright

Judge Wainwright's experience as a Pakeha who worked extensively with Māori offers an interesting contrast to the experiences of Judge Milroy and Judge Fox. Judge Wainwright ended up studying te reo Māori (outside of the law school) almost by accident, and only later did that turn out to have been a pivotal moment in her life. Her experiences learning te reo in the early 1980s could be described as a microcosm of the state of race relations in New Zealand at the time. In hindsight, she considered learning Maori to be a:

... lesson in how people who enter our culture feel when they are similarly unskilled in our language and culture and what it must have been like. ... [I]t gave me a glimpse into the hegemony of the Pakeha world and what Maori had felt like coming into that.

81 For example, the "Sealord" decision: Te Runanga o Wharekauri Rekoku Inc v Attorney-General [1993] 2 NZLR 301 (CA).

82 For example, the "SOE" case: New Zealand Maori Council v Attorney-General [1987] 1 NZLR 641 (HC and CA); and New Zealand Maori Council v Attorney-General [1994] 1 NZLR 513 (PC) [the Broadcasting Assets case]. 
Judge Wainwright was one of the few Pakeha in the class of mainly Māori students. Interestingly, the teacher was a Pakeha woman called Mere Poipoi. Poipoi was her husband's name; her name was actually Mary Boyce. Mere Poipoi was an inspirational and gifted teacher. However, some Māori students objected to being taught by a Pakeha woman and as a result, Mere Poipoi left. Judge Wainwright considered Mere Poipoi's departure to be an enormous loss. That experience was a "little vignette of the awkwardness of the politics around the acquisition of knowledge about te ao Maori and te reo Maori".

There was another experience that shocked Judge Wainwright while learning te reo. She had done very well in the 100-level te reo Māori course, and a senior academic asked to see her. That person had expected her to be Māori. He made that fact evident to Judge Wainwright, remarking along the lines that, "You know we don't run these courses so Pakeha get the best mark." This experience made her realise how detrimental the colonial experience had been for Māori and how resentful some Māori were of Pakeha, although she had not expected the academic staff to carry these prejudices too.

Judge Wainwright reflected on that experience as a formative one as she had previously been "blinkered as to the true nature of race politics in our country". Although the incident with the senior academic was only a "tiny little bit of it", it was an important wake-up call. It made her realise that race relations in New Zealand was complex:

I feel incredibly fortunate as a Pakeha chick that I have been taken into Māori places and hearts and households in a way that far too few of us are, but [that] doesn't lead me to think that any of it is simple or uncomplicated, or that the difficulties that we have will soon be gone.

\section{The law as a tool for change}

This second subsection focuses on Judge Milroy and Judge Fox, and the sense of duty that both women had to use their legal skills to support their iwi and to improve the lives of Māori more generally. In the case of Judge Milroy, her iwi saw legal skills as being valuable to progress the tribe's interests and had encouraged Judge Milroy's father to become a lawyer. The fact that her father never obtained a law degree weighed heavily on Judge Milroy's mind and influenced her decision to go to law school. On her graduation from law school, Professor Graham Smith congratulated her on her achievement and then reminded her of her responsibility to her iwi: "You must become a lawyer and get that experience and then starting using it for the good of the people."

Later in 1986, Judge Milroy would help her iwi to file a claim at the Waitangi Tribunal in relation to the confiscation of some Tühoe lands after the killing of Reverend Carl Völkner in the 19 th century.

Judge Fox realised early on in her degree that the law was a powerful tool to advance the interests of Māori. Whilst at law school, Judge Fox was part of the Māori Law Students' Association, which had made important submissions to Parliament on the drafting of fisheries law 
affecting Māori interests. After graduation, Judge Fox helped to set up a new Māori legal service at her local community law centre. The reason for the new service was to encourage Māori to use community law's resources, which were at the time under-utilised by Māori. The Māori legal service aimed to make the law more accessible to Māori. It provided clinics relevant to Māori and was also active in law reform projects.

The desire to improve the lives of Māori through the law featured strongly in Judge Fox's later career. A particularly memorable period of her career was the important Māori litigation that she worked on in the early 1990s. She did pro bono work for Martin Dawson at Luckie Hain. Luckie Hain was a small law firm that handled all of the New Zealand Māori Council cases - which were led by Justice David Baragwanath and Chief Justice Sian Elias (as they later became). Judge Fox felt excited to be part of history-making for Māori:

\footnotetext{
When you think about that period, there are so many footprints in the sand of that period that have changed the course of history and [Martin's] is one of them. They all came together at the right time. There was him, David Baragwanath, Sian Elias leading the cases in front of Sir Edward Durie who took the [Waitangi] Tribunal from being a non-event to one of the most important constitutional tribunals we have in our legal system now. At the time his decisions were worthy enough for the Court of Appeal, led by Lord Cooke as he became, to take them seriously. If Lord Cooke hadn't been President of the Court of Appeal at the time, if Sian and David hadn't fronted these cases, if Martin hadn't been the solicitor on record, if Eddie Durie hadn't been in charge of the Tribunal, would we have advanced so quickly? I don't know. I don't think so. It was like a time in history when all these footprints converged in the one place on the beach. It doesn't happen very often. And I did the photocopying for them.
}

\section{The impact of race relations on judging}

This section considers how each judge's experience of New Zealand's race relations history influenced the way each judge understood her role as a judge of the Māori Land Court. In 2010, Judge Fox was appointed as the first woman Deputy Chief Judge of the Māori Land Court. In 2004, Judge Wainwright was appointed as the first woman Deputy Chair of the Waitangi Tribunal. Judge Milroy was appointed as the first Māori woman Deputy Chair of the Waitangi Tribunal in 2010.

When asked to describe the Māori Land Court, both Judge Fox and Judge Milroy emphasised the need to view the Māori Land Court in its colonial context. Judge Fox commented on how the Māori Land Court had its "unfortunate" origins in the Native Land Court, which was set up in 1865 to assimilate Māori customary title and turn it into a form of tenure that Māori could trade with. The modern role of the Court was to administer the remains of Māori land, in particular, administering Māori land trusts that covered large tracts of Māori land. Judge Milroy similarly described Te Ture Whenua Maori Act 1993, which constituted the Court, as a "watershed" event for Māori because it gave the Court "the mana, the rangatiratanga, back to the people in terms of their management, use, and ownership and occupation of the land". Judge Milroy commented that working as a judge 
allows her to connect more directly with Māori and their land issues than her previous work as an academic allowed.

Both Judge Fox and Judge Milroy saw the empowerment of Māori as an important objective in their judging. For example, Judge Fox began the practice of sitting with Māori kaumatua (elders) as a way of involving the participation of Māori in the Court. This practice was permitted because the Māori Land Court could apply any rules of tikanga Māori kawa marae protocol in proceedings as the judges deemed to be appropriate. The kaumatua would not influence Judge Fox's decision making but they helped to give gravitas to the proceedings. Judge Fox noticed that Māori loved seeing the kaumatua. They would do mihi, make greetings back, do the karakia and the mana of the Court was thus upheld. Judge Fox also thought that it was appropriate for judges to be skilled in te reo so that people could speak te reo spontaneously, without having an interpreter.

Judge Milroy was deeply aware of the fact that Te Ture Whenua Maori Act was a foreign, Pakeha law imposed on the resolution of Māori disputes. ${ }^{83}$ But she believed it was possible to shape the Court's processes so that Māori could articulate their issues and feel that they were being listened to. Establishing culturally appropriate processes was complex. For example, Judge Milroy commented that at marae sittings, it was sometimes hard to find an appropriate balance between following court protocol and marae protocol. Judge Milroy said that she sometimes felt uncomfortable as a Māori woman telling a kaumatua that it was not yet his turn to speak. Above all, Judge Milroy emphasised the importance of empowering people to resolve their own disputes: ${ }^{84}$

When I'm sitting there hearing these things especially about marae, what I want is for people to have another go and try and work it out for themselves. The last thing I want is make a decision for people on their own marae.

From Judge Milroy's point of view, the Court had a role in trying to get people to talk to each other and figure out how to deal with their own issues, although there was a point at which as the judge, she had to determine how the dispute should be resolved. ${ }^{85}$

Judge Wainwright's interview brings out the perspective of a Pakeha woman sitting as a judge of the Māori Land Court. She too, commented on the colonial history of the Court and how it was often misunderstood. She herself had not initially thought to apply to become a Māori Land Court judge because she thought that only Māori could be appointed to that Court. Apparently, that incorrect view was widely shared. She mentioned that she was reported as being not only the first

83 For more detail, see Stephanie Milroy "Ngā Tikanga Māori and the Courts" (2007) 10 Yearbook of New Zealand Jurisprudence 15.

84 At 20.

85 At $20-21$. 
woman, but also the first Pakeha to be appointed to the Māori Land Court. This was false because historically the Native Land Court and the Māori Land Court had been substantially full of Pakeha, so much so that Judge Wainwright described it as "a very sort of colonial court". Indeed, Sir Edward Durie was the first Māori to be appointed to the Court in 1973. Interestingly, Judge Wainwright said that a number of people had approached her and said that they liked that she was not Māori because she was perceived by some people to be more impartial.

She was acutely aware, however, of her position as a Pakeha woman on the Court. She thought that one of the most important ways she could connect with Māori who came before the Court was to speak their language. Interestingly, there were Māori working in the Court who did not think that they needed to be proficient in te reo. Judge Wainwright recalled an incident where she spoke with a Māori woman who worked at the Waitangi Tribunal and she asked her why she did not learn Māori. The Māori woman's response was that she did not need to learn te reo because she was Māori. Her response made Judge Wainwright think that although Māori may not require other Māori to be able to speak te reo, a Pakeha woman who went to a Māori event and could speak te reo was a powerful indication that the person had invested in Māori culture. That elicited respect and avoided a perception that the person was "just another Pakeha who has been visited on us". Judge Wainwright worked hard to learn Māori, including attending Māori immersion school, an experience she found incredibly challenging, but as a result she reached a level of proficiency that enabled her to communicate freely in te reo.

\section{CONCLUSION}

The recording of these New Zealand women judges' previously unheard life histories provides a powerful narrative that it is possible for women to become leaders in the legal profession - indeed in any field that women choose to apply their skills and passion to. The stories discussed in this article demonstrate the way gender shaped the lives of these women in important ways - whether that was going to law school despite prevailing attitudes that the law was not an appropriate career for girls, or negotiating partnership on terms that made balancing motherhood with work a realistic option. The stories of these judges show that young women can strive for equality in their individual lives, for example, by empowering themselves and other women through women lawyers' associations or by putting themselves forward for leadership positions. Most importantly, the stories of the women judges demonstrate that success in the law (and in life) is not one-dimensional, achieved by becoming a partner, a QC or even a judge - rather, these women judges show us that a satisfying career can be multi-faceted, achieving not only financial security, but also embracing family life, academia, community service, international engagement and more.

On a wider societal level, the recording of the women judges' stories through oral history vividly demonstrates the momentous changes in legal education and the legal profession, where women's participation at the highest levels of the legal profession, whilst remaining remarkable, no longer seems out of reach for young women. The women judges' struggles and successes have made it easier for younger generations of women to flourish. The achievements of women who have gone 
before give younger generations of women the responsibility to continue to advance the interests of women.

But there is a still a long way to go before women will be equal to men in the highest levels of the profession. The gender gap is well documented in Dame Susan Glazebrook's paper, "It is just a matter of time and other myths", where it is noted that the proportion of women in partnerships, in judicial roles, as QCs, and on commercial boards falls far below 50 per cent. ${ }^{86}$ The Oral Histories Project is therefore both a celebration of how far women have progressed in the legal profession and encouragement for today's women in the law to continue to strive for gender equality.

86 Susan Glazebrook "It is just a matter of time and other myths" (paper presented to Get up and Speak 2013, Wellington, 15 August 2013) at 1-2. 